\title{
IAMJ
}

INTERNATIONAL

AYURVEDIC

MEDICAL JOURNAL

\section{REVIEW OF VATAVYADHI w.S.r TO CHARAK SAMHITA}

\author{
$\underline{\text { Archana A. Kulkarni }}^{1}$, Anjali A. Deshpande ${ }^{2}, \underline{\text { Poonam Shete - Mapari }}^{3}$ \\ ${ }^{1}$ Professor, Rog Nidan Dept. \\ ${ }^{2}$ Professor, Kayachikitsa Dept. \\ ${ }^{3}$ Assistant professor, Rasa shastra Dept. \\ BSDT's Ayurved College, Wagholi, Pune, Maharashtra, India
}

Corresponding Author: archana.arukulkarni@gmail.com

https://doi.org/10.46607/iamj0909042021

(Published online: April 2021)

Open Access

(C) International Ayurvedic Medical Journal, India 2021

Article Received: 06/03/2021 - Peer Reviewed: 19/03/2021 - Accepted for Publication: 20/03/2021

Check for updates

\section{ABSTRACT}

Ayurveda is an 'Ancient Science of life'. Ayurveda proposes the concept of Dosha-Dhatu-Mala as one of its basic principles. It classifies biological elements in the body as Vata, Pitta, Kapha. Tridosha begin their role as soon as life starts. These Tridosha maintain the body when they are normal and balanced, termed as Sukha and if there is imbalance and abnormality in these three Dosha, individual become diseased termed as the Dukha. Out of the three Dosha, Vata Dosha is considered supreme because it regulates all functions in the body including movement of the other two Dosha. 'Maharogaadhyaya' of Charak samhita explains classification of diseases according to Doshapradhanya namely Samanyaj and Nanatamaj Vyadhi. The diseases caused due to only one Dosha are termed as Nanatamaj Vyadhi. Vatavyadhi are group of disorders particularly caused by only "Vata dosha". An attempt is made to review various types of Vatavyadhi from Charak Samhita. After critical review, it can be concluded that vitiated Vata can cause various types of diseases, depending upon the Hetu, affected Ashaya, Avayav, Dhatu, Indriya. Detailed study of Vatavyadhi Hetu, Samprapti, types and prognostic factors etc. are very important for academic and clinical success. Thus, understanding of Vatavyadhi helps to decide pathogenesis, prognosis and precise treatment modalities.

Keywords: Avrita Vata, Dhatugatvata, Dhatukshaya, Vatavyadhi. 


\section{INTRODUCTION}

Ayurveda is an 'Ancient Science of life'. The main aim of Ayurveda is to maintain health of healthy person and also to regain good health in diseased one $^{1}$.Dosha-Dhatu-Mala is one of the basic principles of Ayurveda. Ayurveda classifies biological elements viz Vata, Pitta, Kapha. Acharya Sushruta quoted the importance of Tridosha stating that, the universe is maintained by Soma, Surya and Anil in the same manner Kapha, Pitta and Vata Tridosha maintain the individual's health ${ }^{2}$. They are responsible for all the functions and transformations in the body. As soon as the life process starts i.e. the fertilization takes place the Tridosha begin their role to maintain the health of an individual. These Tridosha maintain the body when they are in normal and balanced condition, termed as Sukha and if there is imbalance and abnormality in these three Dosha, individual becomes diseased termed as the Dukha. Acharya Charaka has also described that the bird flying in the sky throughout the day not able to surpass its own shadow in the same way all of the diseases cannot originate apart from tridosha ${ }^{3}$. Out of the three Dosha, Vata Dosha is considered supreme because it regulates all functions in the body including movement of the other two Dosha. The Vatadosha is also responsible for the functions of systems concerned with regulation, signaling, conduction and control of any information or system in our body. Vata in its normalcy maintains the whole body and its systems working in subtypes as Prana, Udana, Vyana, Samana, and Apana. It is the initiator of all kinds of activities within the body, the controller and impellor of all mental functions, and the employer of all sensory faculties. It joins the body tissues and brings compactness to the body, prompts speech, is the origin of touch and sound, is the root cause of auditory and tactile sense faculties, is the causative factor of joy and courage, stimulates the digestive fire and helps in the absorption of the Dosha and ejection of the excretory products. Vata traverses all gross and subtle channels, moulds the embryo shape and is the indicator of continuity of life ${ }^{4}$.

The Vata, when aggravated, afflicts the body with various kinds of diseases and deteriorates or diminishes the strength, complexion, happiness and the life span of an individual. It perturbs the mind, disturbs the sense faculties, destroys, deforms or retains the embryo for longer periods, gives rise to fear, grief, attachment, humility, excessive delirium and takes away life ${ }^{4}$.

In classical text of Charak Samhita very much importance is given to Vatadosha. In sutrasthana twelfth chapter "Vatakalakaliya" while describing the normal and abnormal functions of Tridosha the Vata dosha is discussed more in detail considering its supremacy as the initiator of all functions in the body.

Acharya Charak in "Maharoga Adhyaya" of Sutrasthana describes the classification of diseases according to Doshapradhanya namely Samanyaj and Nanatamaj Vyadhi. The diseases caused due to only one Dosha are termed as Nanatamaj Vyadhi. Vatavyadhi are group of disorders particularly caused by only 'Vata Dosha'. There are as many as eighty types of disorders due to a vitiated Vata only, forty due to Pitta, and twenty due to Kapha ${ }^{5}$.

"Vatavyadhi Chikitsa" Adhaya highlights the five sub classifications of Vata, their habitat and functions. It also explains the etiology, symptomatology, etiopathology and management strategies of various Vatavyadhi. There is no such separate chapter describing diseases of Pitta and Kapha dosha.

A detailed study of the Dosha, their locations and characteristics will help in effective diagnosis or treatment of diseases. It is also mentioned that only Vata is responsible for the transmission of vitiated Dosha to the different organs of the body. Kapha, Pitta and the Dhatu are immobile in nature. Wherever they are carried by the Vata, they cause diseases, just as the wind causes rain in a particular area ${ }^{6}$.

Critical understandings of disease pathology, types, prognostic factors etc. are very important for academic and clinical success. Thus, through understanding of Vata Vyadhi is essential before initiating the treatment of disease. An attempt is made to analyze and understand in detail the different types 
of Vatavyadhi according to Dhatugatata, Ashayagatata, Avayava gatavata, Avarana etc.

Aim and Objective: To review Vatavyadhi and its Ashiti prakar (80 types) from Charak Samhita critically.

Materials and Methods: This is a literary and conceptual article therefore Ayurvedic texts used in this study are Charak Samhita, Sushrut Samhita, Ashtang Hrudaya, Madhav Nidan and their available Commentaries. Also dictionaries like Amarkosha, Monier Williams have been used for references.

\section{Review of Literature and Discussion:}

\section{A. Definition of Vatavyadhi:-}

Vatavyadhi is defined as any special condition caused by vitiated Vata Dosha.

B. Hetu of vitiation of vata dosha ${ }^{7}$ : - The hetu described in Charak Samhita for vitiation of Vata dosha can be divided in two main types i.e. Dhatukshayajanya and Margavrodhjanya Hetu.

Dhatukshayajanya Hetu: Due to intake of dry, cold, deficient and light food; excessive sex, sleeplessness; 1. improper treatments; expelling of Dosha (during the course of treatments like emesis, purgation etc.); or bloodletting, by excessive fasting, swimming, walking, exercising, and physical activity, depletion of body tissue, worry, grief, extreme debility due to protracted diseases; usage of uncomfortable beds or seats; anger, day sleep or even with fright; suppression of natural urges, indigestion, trauma, abstaining from food; injury to vital areas, falling from swift moving elephant, camel or horse (fast moving vehicles) etc. Vata is aggravated. These Hetu are responsible for loss of body tissue by any means. This vitiated Vata gets filled in the vacuous channels in the body and leads to various generalized or localized disorders.

Margavrodhjanya Hetu: Hetu which lead to formation of ama are included in Margavrodhjanya
Hetu. Obstruction to the various channels due to Kapha, mala etc. can also be included in Margavrodhjanya Hetu.

C. Samprapti of Vatavyadhi ${ }^{7}$ :- The aggravation of Vata can be due to Dhatukshaya (diminution of tissue elements) or due to Avarana (obstruction to its pathway). The aggravated Vata vitiates Strotas with its Laghu, Ruksha, Khara, Parusha Guna and makes these Rikta Strotas susceptible to Sthansanshraya (lodging) of Dosha. Commenting on Rikta Strotas, Chakrapani elaborated that there is "Snehadi Guna Shunyatvam". The channels of the body lost their protective sheaths and lost qualities like unctuousness, smoothness and stickiness etc. On occupying the susceptible Strotas the vitiated Vata will produce Ekanga (limited to particular parts of the body) or Sarvanga (afflicting the whole body) Vyadhi. Such Vyadhi which are manifested either in certain portion of the body or the whole body is called Vata Vyadhi.

\section{Classification of Vatavyadhi}

Ashaya gatavata or Vatavyadhi affecting various
Ashayas (Sites) ${ }^{8}$ :-
Gatatva is a unique feature of Vataja
Samprapti. Gatatva of Vata is possible in Dhatu,
Upadhatu, Ashaya (sites or hollow cavities of
organs), Avayava (part or organ), etc. Due to
consumption of Ahitakar Ahara of relatively
higher Kittansha (waste products) leads to depletion
of Dhatu and aggravation of Vatadosha'. This create
Avakasha, Riktata (emptiness) in the body tissue
leading to the engorgement and hyper movement of
aggravated Vata in the site.


Table 1: Ashayagata vata and its lakshanani

\begin{tabular}{|l|l|}
\hline Ashaya & Lakshanani \\
\hline Koshthashritavata & $\begin{array}{l}\text { Urinary retention and constipation, intestinal and epigastric discomforts, Gulma, piles and pain in } \\
\text { flanks. }\end{array}$ \\
\hline Sarvanga kupita vata & $\begin{array}{l}\text { Generalized fasciculation and breaking pain; different types of pain and the generalized joint } \\
\text { crepitus }\end{array}$ \\
\hline Ruda sthita vata & $\begin{array}{l}\text { Retention of feces, urine and flatus; colicky pain, flatulence, renal calculi, micro-calculi; diseases } \\
\text { with atrophy in calf, thigh, pelvis, and the back }\end{array}$ \\
\hline Amashaya sthita vata & $\begin{array}{l}\text { Pain in epigastrium, umbilicus, flanks and abdomen; morbid thirst, eructation, acute gastroenteritis, } \\
\text { cough, dryness of throat and mouth and breathing difficulty }\end{array}$ \\
\hline $\begin{array}{l}\text { Pakwashayasthita } \\
\text { Gata }\end{array}$ & $\begin{array}{l}\text { Gurgling, colicky pain, tympanitis, difficulty in defecation and urination, flatulence and lumbar/ } \\
\text { sacroiliac pain. }\end{array}$ \\
\hline Snayugata vata & $\begin{array}{l}\text { Ophisthotonus or Emprosthotonus, radiculopathy, kyphosis, quadriplegia or hemiplegia. } \\
\text { narrowing of vessels. }\end{array}$ \\
\hline Siragata vata & \begin{tabular}{l} 
Palpatory feeling of air in joints (crepitus), swelling along with painful flexion and extension. \\
\hline Sandhigata vata
\end{tabular} \\
\hline
\end{tabular}

2. Dhatugata vata or Vatavyadhi affecting various Dhatu (tissue) ${ }^{10}$ : -

Gata means to lodge, dwell, locate. Gatatva depend on the Hetu and Khavaigunya or Dhatushaithilya. When Prakopita Vata vitiates the Dhatu it is called as Gata Vata, means Vata Prakop with specific Nidan occurs as initiative factor to interplay with specific Dhatu. Dhatu can be classified into two types Asthayi Dhatu and Sthayi Dhatu. Asthayi Dhatus are the ones which are Dravaswaroop and Parinam
Aapadyamananam (undergoing conversion) and they are being Vikshepita from their Mulasthan throughout the Sharir (Abhivahan) for the purpose of Poshan of the Sthayi Dhatu. This Parinaman and Abhivahan Prakriya takes place in Marga which are known as Strotas; hence Marga is one of the synonyms used for Strotas.

Prakopita Dosha have the capacity to further vitiate both Sthanasta Dhatu as well as Margag Sharir Dhatu.

Table 2: Dhatugata vata and its lakshanani

\begin{tabular}{|l|l|}
\hline Dhatugata & Lakshanani \\
\hline Twakgata vata & $\begin{array}{l}\text { Skin becomes dry, fissured, numb, thin, and blackish. It causes pain along with } \\
\text { erythema and strain and leads to pain in distal end of bones. }\end{array}$ \\
\hline Raktagata vata & $\begin{array}{l}\text { Severe pain with warmth and discoloration; weight loss, anorexia, specific raised } \\
\text { rashes in body and esophageal spasm }\end{array}$ \\
\hline Mamsa medogata vata & $\begin{array}{l}\text { Heaviness of body, pricking pain and as if beaten by a strong rod or fist cuff and } \\
\text { painful severe fatigue }\end{array}$ \\
\hline Shukra gata vata & $\begin{array}{l}\text { Splitting pain of bones and joints, arthralgia, loss of muscle strength, insomnia and } \\
\text { continuous pain. }\end{array}$ \\
\hline Garbhagata vata & $\begin{array}{l}\text { It causes premature ejaculation or anejaculation. It may also lead to preterm or } \\
\text { delayed labor. It may also cause deformity in fetus. }\end{array}$ \\
\hline Shushka garbha due to Bala of Kupita Vata \\
\hline
\end{tabular}

Acharya Caraka has not separately explained the Garbhagatavata but the commentator Cakrapani mentioned Garbhagata Vata.
3. Indriya gata vata or Vatavyadhi affecting various Indriya $^{11}$ :- When vitiated Vata gets in particular Indriya (organ), it either cause Upatapa or Vaiklyam 
(impairment) or Upaghata, Vadha or Vinashama (deformity) of the respective organ. E.g: Ucchaishruti (hard to hear), Badhirya (deafness), Mookatva (aphasia), Vaksanga (stammering speech), Arasadynata (loss of taste sensation), Ghrana-nasha (loss of smell sensation), Timira (loss of vision), Kanthoddhvamsa (hoarseness of voice), Ashabdashravana (tinnitus).

4. Avrita vata or conditions due to obstructed Vata ${ }^{12}$ :- Avarana is another distinct pathology of Vata in which the free mobility or movement is hampered. According to Ayurvediya Shabdakosha the word Avarana means "Avarodha Gatinirodha" i.e. obstruction or resistance or friction to the normal Gati. Vata Dosha is the Gatyatmak Dravya within the Sharir. When normal Gati is hampered or vitiated, Vata becomes Avrita.

When vitiated and increased Pitta, Kapha, Dhatu or Mala severely obstruct the pathway of Vata leads to its Prakopa, and then this condition is termed as Avrita Vata. Charak in context of Madhumeha has used the word Avrita Gati. Chakrapani explains it to be Ruddhagati.

In context of Kasa, Chakrapani says Pratighat means Avarana while in context of Shotha says Badhamarga means Avritamarga. Thus, the word Avarana can be understood as Achchhadan, Avaruddhagati, Sanga, Pidhan, Samvaran, Aakirya, Prachadana, Vestana, Valayana, Pravrita or Samvrita. Thus, Avarana may happen either due to Pitta, Kapha Dosha, Dhatu or Mala. Avarana may also happen in between two subtypes of Vata as the direction of movement of various types of Vata differ. This is called Anyonyavarana ${ }^{13}$.

Avarana further causes diminution of the body nutrient, fluid and other body elements.

Table 3: Avrita Vata and its lakshanani:-

\begin{tabular}{|c|c|c|}
\hline & Avrita Vata & Lakshanani \\
\hline 1 & Vata occluded by Pitta & $\begin{array}{l}\text { Burning sensation, morbid thirst, colic, giddiness, darkness of vision; heart burn } \\
\text { on eating pungent, sour, salt and hot things and craving for cold things. }\end{array}$ \\
\hline 2 & Vata occluded by Kapha & $\begin{array}{l}\text { Excess feeling of cold, heaviness, pain, pacification by pungent and similar other } \\
\text { articles, craving for fasting, exertion, dry and hot things. }\end{array}$ \\
\hline 3 & Vata occluded by blood & $\begin{array}{l}\text { Severe burning, pain in the area between the skin and the flesh, along with edema } \\
\text { and reddish tinge and round patches. }\end{array}$ \\
\hline 4 & Vata occluded by Mamsa & Hard, discoloured boils, and swellings, horripilation and tingling. \\
\hline 5 & Vata occluded by Meda & $\begin{array}{l}\text { Movable, smooth, soft and cold swellings in the body, anorexia. This condition is } \\
\text { known as adhyavata and is difficult to cure. }\end{array}$ \\
\hline 6 & Vata occluded by Asthi & $\begin{array}{l}\text { Patient likes hot touch (local sudation) and pressing. He has splitting pain and } \\
\text { feels as though his body is being pricked with needles. }\end{array}$ \\
\hline 7 & Vata occluded by Majja & $\begin{array}{l}\text { Flexure, bending, curving of the body, pandiculation (stretching and stiffening of } \\
\text { the trunk and extremities), excess yawning, twisting and colicky pain. relief in } \\
\text { pain on pressing with the hand }\end{array}$ \\
\hline 8 & Vata occluded by Shukra & Ejaculation or premature ejaculation or sterility \\
\hline 9 & Vata occluded by food & $\begin{array}{l}\text { Pain in the stomach on ingestion of food and disappearance of pain after } \\
\text { digestion. }\end{array}$ \\
\hline 10 & Vata occluded by urine & Retention of urinary and distension of bladder. \\
\hline 11 & Vata occluded by feces & $\begin{array}{l}\text { Constipation, scissoring type pain in anal region, all unctuous matter ingested is } \\
\text { immediately digested (due to excess dryness in colon), after food intake the } \\
\text { increased distension of abdomen and owing to the pressure of the food ingested } \\
\text { the patient passes dry feces with difficulty and after long delay. Pain in the hips, } \\
\text { groins and back; as the Vata moves in a reverse direction causes epigastric } \\
\text { discomfort. }\end{array}$ \\
\hline
\end{tabular}


Dhatuavrita Vata and Dhatugatavata are the two distinct pathologies as in Dhatugatavata the vitiation of Vata is active. While in Dhatuavrita Vata vitiation of Vata is passive as Gati of Vata is obstructed.

Table 4: Difference between Avrita Vata and Gata Vata:-

\begin{tabular}{|c|c|}
\hline Avrita Vata & Gata Vata \\
\hline Vitiation of Vata is passive & Vitiation of Vata is active \\
\hline $\begin{array}{l}\text { Normally Svanidana (specific Hetu for vitiation) } \\
\text { of Vata } \text { are not responsible }\end{array}$ & Vitiation of Vata by Svanidana. \\
\hline $\begin{array}{l}\text { Only Chala Guna of Vata is involved and it is } \\
\text { diminished in the phenomenon. }\end{array}$ & $\begin{array}{l}\text { Other Guna of Vata are also involved and the Chala Guna } \\
\text { aggravated in the phenomenon. }\end{array}$ \\
\hline Gati of Vata is obstructed. & Gati of Vata is aggravated. \\
\hline Purnata (fullness) in Strotas. & Riktaka (emptiness) in Strotas. \\
\hline Dhatu are Vruddha (increase) or Sama & Dhatu Daurbalya (decrease) present \\
\hline $\begin{array}{l}\text { Avarana possible with other Dosha, Anna, Mala or } \\
\text { individual components of Vata }\end{array}$ & Not possible \\
\hline Avarana by Avayava or Ashaya not possible & Gatatva in Ashaya and Avayava explained \\
\hline Avaraka gets importance in treatment & Vata gets importance in treatment \\
\hline Diagnosis made with Upashaya Anupashaya & Diagnosis with Rupa \\
\hline Severe Complications of Avarana possible & None \\
\hline Successive diminution of Rasadi Dhatu possible & None \\
\hline
\end{tabular}

\section{Vatavyadhi with gati vriddhi as predominant} feature: - Vepathu (tremor), Hriddrava (tachycardia). Vepathu means shaking, trembling or tremor ${ }^{14}$. This term is derived from the Sanskrit root "Vip", meaning to tremble, shake, vibrate, shiver or quiver. Another Sanskrit word for tremble or shake is Kampa and condition known as Vepathu came to be commonly known as Kampavata. Amarkosha mentions Kampa and Vepathu as synonyms referring both as tremor ${ }^{15}$. Hriddrava means rapid throbbing of heart ${ }^{16}$. This is due to increase in Chala Guna of Vata.

6. Vatavyadhi with change in gati as predominant feature: - Udavarta is the disease in which there is Avartana (whirlpool movement) and Urdhva Gamana (upward) of Vata is seen due to retention of Vata, Mootra, Purisha ${ }^{17}$. Vaksha uparodha means Ura Pradeshi Avarodha. It is due to obstruction to normal movement of Vata. Hikka is produce when aggravated Vata deranges the Kapha situated in the Pranavahastrotas resulting obstruction to Pranavayu 18. A hiccup is an involuntary contraction (myoclonic jerk) of the diaphragm that may repeat several times per minute.
7. Vatavyadhi with Akarmanyata as predominant feature: - Ekanga Roga (monoplegia), Sarvanga Roga (quadriplegia), Pakshavadha (hemiplegia), Urusada (loss of movement in thigh), Pangulya (Paraplegia), Khanjatva (Limping) The term Pakshaghata literally means paralysis of one half of the body where "Paksha" denotes any one half of the body. The words "Ghata" denotes the Hanana or to kill. "Aghata" or "Vadha" are also the synonyms for Ghata ${ }^{19}$. The Pakshaghata can be correlated with hemiplegia. The term "hemiplegia" consists of two words "hemi" and "plege". "Hemi" means half and "plege" means a blow or stroke. Thus monoplegia, quadriplegia or hemiplegia implies a total or partial loss of either movement or sensation or both in one, more or all parts of the body.

8. Vatavyadhi with Shoola as predominant feature :- Pada shoola (pain in legs), Janubheda (tearing pain in knee), Gudarti (pain in anus), Vankshan-anaha (sprain in groin), Shronibheda (pain in pelvis girdle), Parshvavamarda (rubbing pain laterally), Udaravesta (twisting pain in abdomen), Vaksha Uddgharsha (rubbing pain in chest), Vaksha Toda (pricking pain in chest), Hanubheda (cracking pain in jaw), Aksibheda 
(cracking pain in eyes), Akshishoola (pain in eyes), Karnashoola (ear ache), Shiro Ruk (headache), Gridhrasi (sciatica), Pindikodveshtana (cramps in calf muscles), Shankhabheda (cracking pain in temporal region of head), Lalata bheda (cracking pain in frontal region of head).

In Ayurvedic texts, various terms such as Ruk, Ruja, Vedana and Shool are commonly used for pain, however, "Shool" is more appropriate term amongst all. It is a condition with state of discomfort to body and mind. Thereby, stating the definition of Shool as experience similar pain like piercing with Samku (Spear) in body of the person ${ }^{20}$. It has been further elaborated that out of Tridosha, vitiated 'Vata' is the main causative factor responsible for all painful conditions ${ }^{21}$. The 'Ruksha' and 'Chala' Guna of Vata are mainly involved in the manifestation of pain.
Different types of pain are explained in Ayurveda in the context of vitiated Vatadosha. Toda (Pricking pain), Bheda (splitting pain), Vyadha (piercing type pain), Veshtana (binding type pain), Prasaranaakunchanavedana (pain during joint movements) and Maharuja (severe pain) etc. Gridhrasi is suggestive of the typical character of pain and also the gait of the patient. Gridhra means vulture. Vulture while eating pierces its beak deeply in the flesh and then draws it forcefully causing severe pain. The pain in Gridhrasi is also of the same kind. Due to persistence of the severe pain the patient has a typical gait. This gait resembles with that of the vulture so the name Gridhrasi. Along with pain Stambh and Spandan are also cardinal features of Gridhrasi $^{22}$.

Table 5: Terminologies in Ayurveda literature regarding various pain sensations

\begin{tabular}{|l|l|l|}
\hline & Type of Vedana & Meaning in English \\
\hline 1 & Bhedan & Splitting type of pain \\
\hline 2 & Shoola & Piercing pain \\
\hline 3 & Sada & ache \\
\hline 4 & Udveshtana & Cramps like pain \\
\hline 5 & Sphutana & Cracking like pain \\
\hline 6 & Udgharsha,Marda & Rubbing type of pain \\
\hline 7 & Toda & Pricking pain \\
\hline 8 & Ruka & Pain \\
\hline
\end{tabular}

9. Vatavyadhi with suptata as predominant feature:

- Pada suptata is numbness or insensible sensation in feet $^{23}$.

Vata is responsible for all sensory and motor functioning of body. Impaired function of Vata produces temporary or permanent Suptata of particular organ.

10. Vatavyadhi with Stambha (stiffness) as predominant feature: - Gulphagraha (stiffness in ankle region), Urustambha (stiffness in thigh), Shephastambha (stiffness in penis), Trikgraha (stiffness in sacral region), Prusthagraha (stiffness in back), Grivastambha (stiffness in neck), Manyastambha (torticollis), Vartmastambha (stiffness in eyelids), Vata Khuddata (pain and stiffness in ankle region), Trikgraha (stiffness in sacral region)
Stambha means cramping, spasticity; rigidity or stiffness ${ }^{24}$. Stambha and Graha are similar in meaning both signify hampered movement of the particular organ. Stambha is due to increased Shita Guna of Vata.

11. Vatavyadhi with Shosha (atrophy) as predominant feature:- Bahu Shosha (wasting of arm), Mukhashosha (dryness in mouth), Vartma Sankocha (entropion).

Shoshan means drying up, emaciation or leads to shrink up ${ }^{25}$. Shosha can be developed as an effect of suffering of previous diseases or many other diseases are also developed as complications of Shosha. Increased in Ruksha and Laghu Guna of Vata causes Shosha. 
12. Vatavyadhi with Raukshya (dryness) as predominant feature: - Nakhabheda (cracking of nails), Vipadika (cracking of soles), Keshabhoomisphutana (cracking of scalp), Oshthabheda (cracking of lips), Dantabheda (cracking over teeth), Raukshya (Roughness), Parushya (coarseness),

Raukshya means to be rough or harsh, to make dry or emaciated. Parushya means roughness or harshness ${ }^{26}$. Bheda is cracking. Bheda also denotes cracking type of pain but here Bheda is used for cracking of particular body organ.

13. Vatavyadhi with Kriyatmaka Vikruti (functional loss) as predominant feature:- Hrinmoha (Cardiac dysfunction), Moha as mentioned by Amarkosha is synonym of Murcha (loss of consciousness) ${ }^{27}$

14. Vatavyadhi with Rachanatmak Vikruti (Structural Changes) as predominant feature:Kubjatva (kyphosis), Vamanatva (dwarfism), Akshivyudasa (squint eye), Bhruvyudasa (twisting in eye brows), Vrushanakshepa (undescended testicle), Danta Shaithilya (loose teeth), Pada bhramsha (foot drop), Janu Vishlesha (dislocation in knee joint), Guda bhrama (rectum prolapse)

Bhramsha denotes the displacement of an entity from its normal position. In the embryonic stage if Vata gets vitiated it produces structural deformities in foetus. Vitiated Vata also leads to some structural changes like Shosha (atrophy or emaciation), Vyas (dilatation or hypertrophy) and Bhramsha (dislocation) in later life.

15.Vatavyadhi affecting Manas: - Vishada (asthenia), Atipralapa (excessive delirium), Anavasthita Chittatva (unstable mind)), Asvapna (Insomnia)

Meaning of Vishada as drooping state, lassitude, depression, lethargy ${ }^{28}$. It is caused by vitiation of Vata and Raja. Vitiation of Vata and Raja gets seated in Hridya and ultimately causes vitiation of mind (Vibhrama) which finally leads to Vishada. According to Charaka Vishada is Shrestha Rogvardhak Bhava. Pralapa indicates incoherent speech. Amarkosha defines Pralapa as 'Anarthakam Vacha' (meaningless talk) ${ }^{29}$. Thus, Pralapa is understood as irrelevant speech.
Anavasthita Chittatva can be seen as one of the symptoms in various mental disorders. It is due to vitiation of Raja Guna of Mana.

Asvapna is Synonyms of Nidranasha. Mind plays an important role in the loss of sleep. Tamo Guna of Mana helps in creating sleep. It is associated with Kapha Dosha and helps in generation of sleep ${ }^{30}$. When mind gets disturbed due to any thought, it increases Rajo Guna which closely resembles with the Vata Dosha. Hence increase in Rajo Guna ultimately increases Vata Dosha and diminishes the effect of Tamo Guna ultimately landing the person in insomnia.

\section{Vatavyadhi with involvement of other Dosha: -} Bhrama refers to giddiness. Amarkosha defines Bhrama as Bhranti and Mithya-mathi (delusion) ${ }^{31}$ and Tama Darshan is black out or Andhkara (Feeling of darkness in front of eye) ${ }^{32}$. Both these symptoms are mentioned in Pittavrita Vata.

In Madhav Nidan it is stated that Bhrama is due to prominence of Rajo Dosha of Manas and Pitta and Vata of Sharir Dosha ${ }^{33}$.

17. Vatavyadhi with Aatmarumpa as predominant feature:- Kashayasyata (astringent taste in mouth) Shavarunavabhasata (black reddish appearance), Jrumbha (Yawning).These symptoms are specifically seen in various Vatavyadhi.

18. Vatavyadhi with Vegaavastha and Avegaavastha (Episodic nature):- Akshepaka (clonic convulsions), Dandaka (tonic convulsions), Ardit etc

In Akshepaka the provoked Vata contracts vessels, tendons and ligaments of the hands and feet cause episodic contraction in different parts of the body. When Vata causes rigidity of muscles of the hands, feet, head, back and hips, so that the body becomes stiff as a stick, is called as Dandaka.

While describing Ardit, the excessively increased Vata affects Sharirdh (one half of the body), it diminishes the blood there, leads to contracture of arm, leg and knee of the affected half and causes distortion of one side of the face and produces asymmetry of the nose, eye brow, fore head, eye and jaw.

Some Vata Vyadhi like Ardit show Vega-Avastha and Avega-Avastha (episodic). When there is Vega- 
Avastha, disease symptoms worsen while these symptoms get subside in Avega-Avastha ${ }^{34}$.

\section{E. Nomenclature of Vatavyadhi: - All} the Vata disorders cannot be named or explained. They should be understood on the basis of site of affliction as well as nomenclature.

F. Sadhyasadhyata of Vatavyadhi ${ }^{35}$ :- Sandhichuti (joint dislocation), Hanustambha (lock jaw), Kunjan (contracture), Kubjatva (kyphosis), Ardit (facial paralysis), Pakshaghata (hemiplegia), Ansashosha (atrophy of a part), Pagutva (paraplegia), Khuddavata (arthritis), Stambha (stiffness), Aadhyavata (rheumatic conditions) and Majja Asthi Gata Vatavyadhi (disorders due to affliction of vata in the marrow) all these are asadhya on account of their seriousness of the sthana (seat) affected, may or may not be cured even after deliberate treatment. These can be cured only when they are of recent origin in strong patient and without any complications.

G. Charak Samhita enlisted eighty-one Vata Vyadhi. In "Ayurvedipika" while commenting on number of Vata Vikara, the Ashiti numbers is due to predominantly occurrence of Vata Vyadhi and are merely representatives of Aparisankhyeatva (innumerable) $^{36}$. Even though the diseases caused by it are innumerable, starting from Nakhabheda (nail splitting), the major eighty diseases enlisted in Sutra sthana are important.

\section{CONCLUSION}

The entire body is the dwelling of all the three Dosha, balance and imbalance leads to good health or diseased state. Vata in its normalcy maintains the mechanism of whole body. It performs all kinds of body activities, help sense organs to gather the information and controls mind. Thus the functions of Vata Dosha correspond not only to the functions of nervous system but also to the functions of system concerned with regulation, signalling, conduction and control of information in the body. Maharoga Adhyaya the twentieth chapter from the Sutra Sthan of Charak Samhita deals with Nanatmajavikara and Chikitsa. Nanatmajavikara are the diseases caused due to involvement of single Dosha. The provocation of Vata is either due to Dhatukshaya or due to Avarana.

After critical review of various types of Vatavyadhis from Charak Samhita it can be concluded that vitiated Vata can cause various types of diseases, depending upon the Hetu, affected Ashaya (site), Dhatu (body tissue), Indriya (sense organ or motor organ). As Vata is Gatyatmak Dosha its Gati may get obstructed by another Dosha or Dhatu or due to its own sub types. Gati Vriddhi, Akarmanyata and change in Gati is observed in various disease pathology of Vatadosha. Gunatmak Vruddhi like increase in Rukshata, Parushata, Kharata, Shitata is seen in some diseases. Shoola is the most predominant symptom present in most of the Vatavyadhi. Stamba, Graha of organ is produced due to increase in Shita Guna of Vata. In the embryonic stage if it gets vitiated it produces structural and functional deformities in foetus. Vitiated Vata also leads to some structural changes like Shosha (atrophy or emaciation), Vyas (dilatation or hypertrophy), Bhramsha (dislocation), etc. in later life. Vata when affects the Mana can cause Vishada, Atipralap, etc.

In nutshell, vitiated Vata affects all the foremost systems of body like musculo-skeletal, neuroharmonal, neuromuscular, circulatory. Perturbed Vata causes chronic degenerative changes in organs. Thus, study of classification of Vatavyadhi helps to decide pathogenesis, prognosis and precise treatment modalities.

\section{REFERENCES}

1. Vd. Jadavaji Trikamji Acharya, Charak Samhita Of Agnivesha Revised By Charak And Dridhabala With Ayurved Dipika Vyakha Of Chakrapanidatta, Sutrasthan 30, Arthedashmahamooliya Adhyaya, Verse 26, Reprint, Krishnadas Academy, Varanasi, 2000, Page No.187.

2. Priyavrat Sharma, Sushrutasamhita Of Sushruta With English Translation And Dalhana's, Commentary Along With Critical Notes On Sutrasthana, Sutrasthana 21, Vryana Prashniya Adhyaya,Verse 8, $1^{\text {ST }}$ Edition, Chaukhamba Vishvabharati, Varanasi, 1999, Page No 226. 
3. Vd. Jadavaji Trikamji Acharya, Charak Samhita Of Agnivesha, Revised By Charak And Dridhabala With Ayurved Dipika Vyakha Of Chakrapanidatta, Sutrasthan 19, Ashtodariy Adhyaya, Verse 05, Reprint, Krishnadas Academy, Varanasi, 2000, Page No.111.

4. Vd. Jadavaji Trikamji Acharya, Charak Samhita Of Agnivesha, Revised By Charak And Dridhabala With Ayurved Dipika Vyakha Of Chakrapanidatta, Sutrasthan 12, Vatakalakaliya Adhyaya, Verse 08, Reprint, Krishnadas Academy, Varanasi, 2000, Page No.79-80.

5. Vd. Jadavaji Trikamji Acharya, Charak Samhita Of Agnivesha,Revised By Charak And Dridhabala With Ayurved Dipika Vyakha Of Chakrapanidatta, Sutrasthan 20, Maharoga Adhyaya, Verse 10, Reprint, Krishnadas Academy, Varanasi, 2000, Page No.113.

6. Dr. Brahmananda Tripathi, Sarangdhar Samhita Of Pandita Sarngadharacarya Containing Anjananidana Of Maharshi Agnivesh Annoted With Dipika Hindi Commentary, Purva Khanda 5, Verse 43, Chaukhamba Surbharti Prakashan, Varanasi, 2012, Page No. 60.

7. Vd. Jadavaji Trikamji Acharya, Charak Samhita Of Agnivesha,Revised By Charak And Dridhabala With Ayurved Dipika Vyakha Of Chakrapanidatta, Chikitsa Sthana 28, Vata Vyadhi Chikitsa, Verse 15-18, Reprint ,Krishnadas Academy,Varanasi,2000, Page No.617.

8. Vd. Jadavaji Trikamji Acharya, Charak Samhita Of Agnivesha, Revised By Charak And Dridhabala With Ayurved Dipika Vyakha Of Chakrapanidatta, Chikitsa Sthana 28, Vata Vyadhi Chikitsa, Verse 24-28, 35-37, Reprint, Krishnadas Academy, Varanasi,2000, Page No.617-618.

9. Vd. Jadavaji Trikamji Acharya, Charak Samhita Of Agnivesha, Revised By Charak And Dridhabala With Ayurved Dipika Vyakha Of Chakrapanidatta, Sutrasthan 28, Vividhashitpitya Adhyaya, Verse 4, Reprint, Krishnadas Academy, Varanasi, 2000, Page No.175.

10. Vd. Jadavaji Trikamji Acharya, Charak Samhita Of Agnivesha, Revised By Charak And Dridhabala With Ayurved Dipika Vyakha Of Chakrapanidatta, Chikitsa Sthana 28, Vata Vyadhi Chikitsa, Verse 30-34, $4^{\text {th }}$ edition, Chaukhamba Sanskrit Sansthan, Varanasi, 1994, Page No.617-618.

11. Vd. Jadavaji Trikamji Acharya, Charak Samhita Of Agnivesha, Revised By Charak And Dridhabala With Ayurved Dipika Vyakha Of Chakrapanidatta, Chikitsa Sthana 28, Vata Vyadhi Chikitsa, Verse 28, $4^{\text {th }}$ edition,
Chaukhamba Sanskrit Sansthan, Varanasi, 1994, Page No.617-618.

12. Vd. Jadavaji Trikamji Acharya, Charak Samhita Of Agnivesha, Revised By Charak And Dridhabala With Ayurved Dipika Vyakha Of Chakrapanidatta, Chikitsa Sthana 28, Vata Vyadhi Chikitsa, Verse 58-71, Reprint, Krishnadas Academy, Varanasi,2000, Page No.619620

13. Vd. Jadavaji Trikamji Acharya, Charak Samhita Of Agnivesha, Revised By Charak And Dridhabala With Ayurved Dipika Vyakha Of Chakrapanidatta, Chikitsa Sthana 28, Vata Vyadhi Chikitsa, Verse 199-201, Reprint, Krishnadas Academy, Varanasi, 2000, Page No.625.

14. Sir. Monier Monier - Williams, A Sanskrit - English Dictionary, Motilal Banarasidass Publishers, Delhi, $1^{\text {st }}$ Indian Edition 1899, Reprint 1990, Page No.1018.

15. Shri. Manna Lal 'Abhimanyu', Amarakosa Of Shri Amarasinha With Hindi Translation'Dhara, Pratham Kanda, 7-Natyavarga, Chowkhambha Vidya Bhavan, Varanasi, Edition 1995, Page No.42.

16. Sir. Monier Monier - Williams, A Sanskrit - English Dictionary, Motilal Banarasidass Publishers, Delhi, $1^{\text {st }}$ Indian Edition 1899, Reprint 1990, Page No.1302.

17. Paradakara Hari Sadasiva Sastri of Astanga Hrudaya Of Vagbhata, Nidana Sthana, Chapter 10, Verse no 24, Chaukhamba Orientalia, Varanasi, 2016, Page No. 504.

18. Vd. Jadavaji Trikamji Acharya, Charak Samhita Of Agnivesha, Revised By Charak And Dridhabala With Ayurved Dipika Vyakha Of Chakrapanidatta, Chikitsa Sthana 17, Hikka-Shwasa Chikitsa, Verse 17-18, IV ${ }^{\text {th }}$ edition, Chaukhamba Sanskrit Sansthan, Varanasi, 1994, Page No 533.

19. Shri. Manna Lal 'Abhimanyu', Amarakosa Of Shri Amarasinha With Hindi Translation'Dhara, Dwitiya Kanda, 9-Vaishya Varga, Verse 115, Chowkhambha Vidya Bhavan, Varanasi, Edition 1995, Page No.194.

20. Dr. Laxmidhar Dwivedi, Susruta Samhita Text Wih English Ntranslation By Kaviraj Kunjalal Bhishagratna, Uttartantra Adhaya 42, Gulmapratishedh,Verse 73-76, Chaukhamba Sanskrit Series, $1^{\text {st }}$ Edition 1999,Page No 436.

21. Priyavrat Sharma, Sushrutasamhita Of Sushruta With English Translation And Dalhana's Commentary Along With Critical Notes On Sutrasthana, Sutrasthana 17, Aampakwaaishaniya Adhyaya, Verse 7, $1^{\text {ST }}$ Edition,Chaukhamba Vishvabharati, Varanasi, 1999, Page No 189. 
22. Vd. Jadavaji Trikamji Acharya, Charak Samhita Of Agnivesha, Revised By Charak And Dridhabala With Ayurved Dipika Vyakha Of Chakrapanidatta, Chikitsa Sthana 28, Vata Vyadhi Chikitsa, Verse 56, Reprint, Krishnadas Academy, Varanasi, 2000, Page No.619.

23. Sir. Monier Monier - Williams, A Sanskrit - English Dictionary, Motilal Banarasidass Publishers, Delhi, $1^{\text {st }}$ Indian Edition 1899, Reprint 1990, Page No.1230.

24. Sir. Monier Monier - Williams, A Sanskrit - English Dictionary, Motilal Banarasidass Publishers, Delhi, $1^{\text {st }}$ Indian Edition 1899, Reprint 1990, Page No.1258.

25. Dr. Laxmidhar Dwivedi, Susruta Samhita Text Wih English Ntranslation By Kaviraj Kunjalal Bhishagratna, Uttartantra Adhaya 41, Shoshapratishedh, Verse 2-3, Chaukhamba Sanskrit Series, $1^{\text {st }}$ Edition 1999, Page No 411

26. Sir. Monier Monier - Williams, A Sanskrit - English Dictionary, Motilal Banarasidass Publishers, Delhi, $1^{\text {st }}$ Indian Edition 1899, Reprint 1990, Page No.621

27. Shri. Manna Lal 'Abhimanyu', Amarakosa Of Shri Amarasinha With Hindi Translation 'Dhara', Dwitiya Kanda, 8-Kshatriya Varga, Verse 109, Chowkhambha Vidya Bhavan, Varanasi, Edition 1995, Page No.194.

28. Sir. Monier Monier - Williams, A Sanskrit - English Dictionary, Motilal Banarasidass Publishers, Delhi, $1^{\text {st }}$ Indian Edition 1899, Reprint 1990, Page No.996.

29. Shri. Manna Lal 'Abhimanyu', Amarakosa Of Shri Amarasinha With Hindi Translation 'Dhara', Pratham Kanda, Shabdadi Varga, Verse 15, Chowkhambha Vidya Bhavan, Varanasi, Edition 1995, Page No.31.

30. Vd. Jadavaji Trikamji Acharya, Charak Samhita Of Agnivesha,Revised By Charak And Dridhabala With Ayurved Dipika Vyakha Of Chakrapanidatta, Sutra Sthana 21, Ashtauninditiya Adhaya, Verse 58, Reprint ,Krishnadas Academy,Varanasi,2000,Page No.119

31. Shri. Manna Lal 'Abhimanyu', Amarakosa Of Shri Amarasinha With Hindi Translation 'Dhara' Pratham Kanda,5 Dhi Varga, Verse 4, Chowkhambha Vidya Bhavan, Varanasi, Edition 1995, Page No.24.

32. Shri. Manna Lal 'Abhimanyu', Amarakosa Of Shri Amarasinha With Hindi Translation 'Dhara', Pratham Kanda,8 Patalbhogi Varga, Verse 3, Chowkhambha Vidya Bhavan, Varanasi, Edition 1995, Page No.42

33. Prof. K.R. Srikanta Murthy, Madhava Nidanam of Madhavakar (Text with English translation, critical introduction and appendices), Adhaya 17, Murchabhrama nidanam, verse 1, Page 386-387.

34. Vd. Jadavaji Trikamji Acharya, Charak Samhita Of Agnivesha, Revised By Charak And Dridhabala With
Ayurved Dipika Vyakha Of Chakrapanidatta, Chikitsa Sthana 28, Vata Vyadhi Chikitsa, Verse 52, Reprint, Krishnadas Academy, Varanasi, 2000, Page No.619.

35. Vd. Jadavaji Trikamji Acharya, Charak Samhita Of Agnivesha, Revised By Charak And Dridhabala With Ayurved Dipika Vyakha Of Chakrapanidatta, Chikitsa Sthana 28, Vata Vyadhi Chikitsa, Verse 72-73, Reprint, Krishnadas Academy, Varanasi, 2000, Page No.620.

36. Vd. Jadavaji Trikamji Acharya, Charak Samhita Of Agnivesha, Revised By Charak And Dridhabala With Ayurved Dipika Vyakha Of Chakrapanidatta, Sutra sthana 20, Vatakalakaliya Adhyaya, Verse 11, Reprint, Krishnadas Academy, Varanasi, 2000, Page No.113.

\section{Source of Support: Nil \\ Conflict of Interest: None Declared}

How to cite this URL: Archana A. Kulkarni et al: Review Of Vatavyadhi W.S.R To Charak Samhita. International Ayurvedic Medical Journal \{online\} 2021 \{cited April, 2021\} Available from: http://www.iamj.in/posts/images/upload/743 753.pdf 